\title{
HISTÓRIAS LITERÁRIAS NACIONAIS: AS LIMITAÇÕES DE UMA PERSPECTIVA
}

\section{NATIONAL LITERARY HISTORIES: THE LIMITATIONS OF A PERSPECTIVE}

\author{
Lourival da Silva Burlamaqui Neto* \\ UFPE
}

Resumo: Este trabalho analisa a noção de literatura nacional, considerando-a uma perspectiva ordenadora, porém, sempre excludente. A limitação desse conceito advém de seu princípio configurador: a nação. Essa definição, surgida na virada do século XVIII para o XIX, projeta um olhar anacrônico sobre o passado, aproveitando-o na medida em que seus eventos prenunciavam a mentalidade nacional. Demonstra-se que essa mesma deficiência aparece nas histórias literárias nacionais. Essas, no afã de estruturar uma genealogia de obras que expressasse o sentimento de pertencimento a uma nação, desconsideravam as formas e categorias estéticas vigentes em outros contextos e sedimentavam uma significação, acentuando o teor documental dos textos. Assim, no primeiro tópico desse artigo, aproxima-se a totalidade identitária nacional das totalidades ontológicas e políticas presentes, respectivamente, na Grécia Homérica e nas monarquias políticas. No tópico seguinte, elenca-se as formas responsáveis pela materialização ficcional de cada uma dessas totalidades, associando-as com os gêneros vigentes em cada contexto. Na terceira seção apontase as limitações do conceito literatura nacional a partir de uma rápida análise da noção de sistema literário de Antonio Candido.

Palavras-chave: Nação. Forma. História literária.

Abstract: This work analizes the definition of national literature, considering it a sort perspective, but always excluding. The limitation of this concept comes from its basic principle: the nation. This definition, appeared in the passage of eighteenth century to the nineteenth century, designs an anachronistic view to the past, availing just the events that announces the national mentality. We demonstrate that this deficiency also happens in the national literary histories. These, trying to organize a genealogy of works which express the feeling of beloging to a nation, disconsidered the forms and aesthetics categories of the past, consolidating a significance and increasing the documental content of the texts. In the first section of this article, we present the ontological totality, the political totality of Homeric Greece and political monarchies respectively, approaching them with the national identity. In the second topic, we present the forms responsible by the fictional materialization of these totalities, associating them with genres theories. In the third section, we indicate the limitations of the national literature concept, analyzing the notion of literary system by Antonio Candido.

Keywords: Nation. Form. Literary History.

\author{
* Doutorando em \\ teoria da literatura \\ pelo Programa de \\ Pós-Graduação \\ em Letras da \\ Universidade Federal \\ de Pernambuco \\ (UFPE). E-mail: \\ lourivalburlamaqui@ \\ outlook.com
}




\section{A natureza, o império e a nação: as totalidades possíveis}

Em A Teoria do Romance (2012), Georg Lukács propôs uma hipótese de natureza ontológica para o surgimento dessa forma narrativa. Segundo o pensador húngaro, o dado crucial para a popularização e o consequente estabelecimento do romance como forma literária da modernidade seria a relação entre o indivíduo e o mundo circundante. No mundo homérico, mythos e ananke funcionavam como véus mediadores das relações entre o ser humano e a natureza. Esses tecidos agasalhavam os fenômenos, concedendo-lhe significações e tornando legítima a realidade. Na modernidade, por sua vez, a subjetividade perscrutaria o mundo empírico, aprofundando o conhecimento do sujeito sobre o ambiente à sua volta, mas, desestabilizaria a relação entre essas duas estâncias. Assim, ao homem moderno, a integração primordial com a natureza já não seria possível.

A conjectura de Lukács, à medida que elenca o nexo entre indivíduo e mundo à condição de baliza determinante para a constituição dos gêneros literários, pressupõe: I) A reflexão sobre o conceito de sujeito na antiguidade e na modernidade; II) Diferentes posturas do ser diante da natureza. Assim, na Grécia homérica, o homem era construído pela união de sua extensão corpórea, o vigor ou a letargia física, com suas disposições anímicas, ou seja, seus anseios espontâneos ou pareceres refletidos. Essa união entre a materialidade e os processos mentais seria responsável pelas atitudes dos personagens homéricos. Tais ações constituiriam a quintessência do ser, pois, esses atos o encerrariam em uma teia que, urdida por si próprio, poderia ser denominada destino (Ananke). A façanha materializada em fortuna definiria o âmago do homem homérico, integrando-o ou no seio da natureza ou no interior da comunidade. Dessa forma, independentemente de serem dignas de louvor ou reprovação, a ira (menin) de Aquiles e a astúcia (metis) de Odisseu inseria-os no mundo, fazendo a perfeita conexão entre interior e exterior e diluindo tais categorias. Lukács (2012, p. 25) a esse respeito, afirma:

Todo ato da alma torna-se, pois, significativo e integrado nessa dualidade: perfeito no sentido e perfeito para os sentidos; integrado porque a alma repousa em si durante a ação; integrado, porque seu ato desprende-se dela e, tornado si mesmo, encontra um centro próprio e traça a seu redor uma circunferência fechada.

Nesse ínterim, outro importante elemento produtor de sentidos era o mythos. A explicação mítica, ao mesmo tempo em que "emanava de", "sobrepunha” algum fato empírico, transformando os fenômenos naturais em dados repletos de significados e criando associações diretas entre esses e as ações humanas. Assim, a natureza não era uma fonte de questionamentos, mas um plano do qual emanava respostas. Tanto mythos quanto ananke circunscreviam o homem em uma cultura fechada (LUKÁCS, 2012, p. 25) 
na qual cada ato humano estava repleto de significados e cada elemento possuía uma função coerente no interior de certas estruturas.

A dimensão ontológica da teorização de Lukács e seu conceito de forma, associável não com as peculiaridades estruturais da obra, mas com o arranjo imposto à vida no interior dessa ${ }^{1}$, ao tempo em que concediam originalidade a sua reflexão, restringiam em demasia as obras passíveis de inclusão na grande épica da antiguidade. Somente os textos homéricos, anteriores ao logos filosófico e a qualquer noção de estado, apresentavam um ser completamente integrado à natureza e que encontrava na sua essência a justificativa para suas atitudes. ${ }^{2}$

A Eneida (2014) de Virgílio, por sua vez, apresentava protagonistas de individualidade arrefecida. Nesse texto, a imagem do herói presente nos poemas de Homero, ou seja, o homem que a cada atitude expunha e constituía sua essência, é apagada e, em seu lugar, surge a personagem que guerreia pela sensação de pertencimento a um império. Assim, no épico virgiliano, a guerra era apenas um meio para se alcançar determinado fim. ${ }^{3}$ Buscavase uma justificativa para conflitos que não eram dignos de memória per si, tornando-se necessários apenas para que a grandeza de Roma se efetivasse.

Após essa consideração, uma pergunta faz-se pertinente: no poema do escritor romano, excluído por Lukács de sua teorização, ainda é possível falar de completude? Sim, a totalidade, porém, já não é de ordem ontológica, não se estabelecendo entre sujeito e mundo, entre imanência e transcendência, mas entre o indivíduo e o império, tratando-se de uma integração de ordem política. Quint (1989, p. 11-13, Tradução nossa), comentando esse aspecto, pondera:

A Eneida traça uma luta por fortalecimento e se constitui ao mesmo tempo como narrativa que é o resultado e o meio desse fortalecimento: essa, porém, não é a luta de uma psique individual, mas de uma coletividade política. O contexto político do poema de Virgílio deixa-nos atentos ao fato de que esse [...] está fazendo um trabalho ideológico: ele universaliza o particular e, naquela que é uma das operações centrais da ideologia, apresenta um arranjo político e social como dado - como se fosse inevitável e de alguma forma predeterminado. (Tradução nossa)

Dessa forma, o texto virgiliano assimilava os discursos verossímeis, transmutando-os, em suas tramas, estruturas e personagens, e os reverberava, posteriormente, na ocasião de sua leitura ou escuta, de volta para a sociedade. A Eneida constituía-se, assim, em um repositório de referências simbólicas (ações, tipos ilustres, episódios notáveis) que atribuía sentido ao indivíduo que a lia, permitindo que esse construísse uma percepção de si próprio enquanto ser integrado a uma ordem ou império monárquico.

Se no texto homérico, um modo de agir originava a essência de uma personagem, efetivando-o em um destino perene e o encaixando no seio da
${ }^{1}$ A forma, para

Lukács, se caracterizava pelo modo como ordenava os eventos vivenciados pelo ser, concedendo realce a alguns e negligenciando outros, ou seja, pelo arranjo que impunha às relações, com o mundo, da vida apresentada em seu interior. A seguinte passagem de A metafísica da tragédia é esclarecedora:

"A forma é a juíza suprema da vida. O poder de configuração é uma força julgadora, uma força ética, e toda obra artisticamente configurada contém um juízo de valor. Todo tipo de configuração artística [...] é um degrau na hierarquia das possibilidades de vida [...]" (LUKACS, 2015a, p. 242)

2 Não por acaso para Lukács (2012, p. 32) a pergunta definidora da epopeia seria: "Como pode a vida tornar-se essencial ?”

${ }^{3}$ Enquanto no poema homérico era pressuposto para a própria constituição do ser. 
natureza, no épico de Virgílio, a relação entre homem e mundo era mediada por um constructo humano: a organização política.

Na modernidade, por seu turno, coube à nação, substituindo a configuração monárquica, cumprir essa função acolhedora, integrando a eventualidade em uma trama, conferindo ao episódio ocasional uma disposição e um significado próprio em um enredo orgânico. A assimilação operada pelo nacionalismo, entretanto, distinguiu-se das demais por sua motivação subjetiva e autoconsciente. Na Grécia homérica, a dimensão mítica concedia significados à natureza e à ação do homem. Na Roma antiga, posterior ao logos filosófico, os sentidos já não eram evidentes, porém, o destino do império estava associado não apenas à perícia dos governantes mas também aos desígnios deíficos. ${ }^{4}$ Os estados monárquicos renascentistas, por sua vez, possuíam uma explicação religiosa para suas rígidas estratificações sociais. Assim, para que a ideia moderna de nação surgisse, eram necessárias algumas alterações na maneira do homem conceber o mundo.

É possível elencar dois traços centrais para o surgimento da consciência nacional: I) O racionalismo iluminista responsável pelo abrandamento das explicações religiosas do mundo; II) A apreensão cronológica do tempo que o concebe como uma tessitura na qual os episódios estão encadeados em uma progressão em que é possível discernir presente, passado e as relações de causa e consequência estabelecida entre os fatos. Assim, o elemento sancionador de um estado nacional não seria a vontade divina, mas os anseios de homens conscientes da autoridade que cinge seus anelos coletivos, tornando-os a viga legitimadora de um estado político. Esses, no curso de um tempo cronológico, já se concebiam como membros de uma comunidade que atravessava um determinado intervalo temporal.

Essa temporalidade transversal enquanto traço viabilizador da nação recebeu atenção nos escritos de dois importantes teóricos do nacionalismo: Stuart Hall e Eric Hobsbawn. Para Hall, a nação é “[...] um sistema de representação cultural [...]” (2003, p. 49), ou seja, um conjunto de referências simbólicas, por vezes, antiquíssimas, que atribuem sentido de nacionalidade a eventos e indivíduos, permitindo que estes construam uma ideia sobre si próprios. Esta identificação, entretanto, não é uma via de mão única. Se o indivíduo, inicialmente, adquire noção de sua nacionalidade através da correspondência com determinadas práticas, posteriormente, sua aceitação de tais parâmetros culturais irá se converter em balizas orientadoras para a reprodução dessas velhas referências. Tais práticas simbólicas, datas, costumes e enredos estão dispostos no curso da narrativa nacional, espalhados em um arco temporal que vai desde o primitivo mito fundacional até o instante em que algum indivíduo imagina-se filiado a determinada nação apreendendo para si tais referências que concedem “[...] significado e importância à nossa monótona existência, conectando nossas vidas cotidianas com um destino nacional que preexiste a nós e continua existindo após nossa morte” (2003, p. 52).

\footnotetext{
${ }^{4}$ Algumas passagens da Eneida exemplificam bem essa visão do homem enquanto ser ainda dependente da potência deísta. A proposição do poema, nesse sentido, é exemplar: "A impulso dos deuses por muito/ tempo nos mares e em terras vagou sob as iras de Juno,/ guerras sem fim sustentou para as bases lançar da cidade/ e ao Lácio os deuses trazer [...]" (VIRGÍlIO, 2014, p. 73).
} 
Em A invenção das tradições (2012), Eric Hobsbawn também pensa a nação como um continuum temporal. Embora o nacionalismo não se configure como o fulcro das reflexões do autor neste ensaio, o teórico admite que as nações assentam seus discursos legitimadores sobre práticas usualmente apreciadas como antigas. Uma investigação rigorosa, entretanto, demonstra a brevidade de tais referências. O historiador argumenta que estas tradições são atos e cerimônias habituais, normatizadas por princípios implícitos, nem sempre claros aos que as reproduzem. A repetição de tais ritos busca imprimir alguma ideologia, o que pressupõe a continuidade e a imutabilidade que reiteram determinado valor e postura. Essas tradições, para Hobsbawn, sancionariam a coesão social, os padrões de comportamento e a ideia de nação como algo que possui suas origens em uma antiguidade distante. Por exemplo, os românticos brasileiros, geração coeva à proclamação da independência, adotaram o índio como símbolo válido para o nascente império, concedendo-lhe dignidade fictícia, ombreando-o ao europeu e o alçando a altas categorias idealistas. A adoção do índio como imagem sintetizadora da nova nação buscava conceder origens remotas ${ }^{5}$ ao Brasil além de remodelar o material histórico dos séculos XVI, XVII e XVIII.

Esse breve panorama permitiu o discernimento de três espécies de totalidade: I) Uma totalidade ontológica no texto homérico; II) Uma totalidade política que, iniciando na Roma de Augusto e, consequentemente, na Eneida, foi o modelo para as monarquias do Renascimento e seus épicos; III) Uma totalidade identitária visto que o membro de uma nação sente-se inserido nessa, à medida que comunga das referências culturais dos demais integrantes. Dessa forma, embora cada um desses contextos sócio históricos possua uma interpretação peculiar da natureza e uma concepção própria do homem, todos compartilham do mesmo princípio estruturador de significados: a relação entre o ser e uma estância configuradora de sentidos no interior da qual os atos do sujeito se condensam em um destino. No mundo homérico, assim, o mythos norteava o homem em face dos fenômenos naturais e ananke estabelecia vínculos entre suas atitudes e a fortuna. Na modernidade, por sua vez, a nação cumpre papel análogo, o indivíduo, assimilando uma série de referências culturais, espécies de mitos modernos, passa a se enxergar como parte de um todo e seu destino está intrinsicamente associado a esse.

\section{As formas: a apreensão ficcional das totalidades}

Cada época possui nuances literárias próprias. Essas características podem ser discernidas com maior clareza no tratamento que um período dá aos gêneros literários, ou seja, é forçoso averiguar como um ínterim arranja-os ou reorganiza-os para se compreender a construção ficcional dessa época e a relação texto/contexto, pois, são os gêneros que medeiam, respectivamente, essa criação e esse nexo.
${ }^{5}$ Anderson (2017, p. 38), comentando essa projeção de um passado operado pela mentalidade nacionalista, pondera: "Então foi preciso que houvesse uma transformação secular da fatalidade em continuidade [...]. Admite-se normalmente que os estados nacionais são novos e históricos ao passo que as nações a que eles dão expressão política sempre assomam de um passado imemorial [...]”. 
Em Mímesis (2013), Erich Auerbach, examinando os vínculos entre cenas literárias e o real, elencou a ordenação dos gêneros literários que, associadas a estruturas sociopolíticas, podiam ser modificadas sempre que essas sofressem abalos, ${ }^{6}$ à condição de filtros que circunscreviam uma maneira particular de apreender o mundo e a história. O exame de Auerbach demonstrou que, por razões distintas, em algumas épocas a antiga teoria dos gêneros ${ }^{7}$ que predicava uma distinção rígida entre os estilos alto, mediano e baixo era endossada, enquanto em outras era rechaçada.

Além desse aspecto, as múltiplas práticas sociais de povos distintos constituíam-se como enquadramentos que circunscreveriam uma maneira particular de enxergar o real e a história. Logo, épocas e contextos diferentes pressuporiam compreensões teleológicas e ontológicas próprias que, por si só, já bastariam à consumação de modelos peculiares de representação (Vejase, por exemplo, os modelos de totalidade apresentados no tópico anterior).

Dessa forma, no segundo capítulo de Mímesis (2013, p. 21-42), ao analisar a ardileza e a tagarelice de um vendilhão, personagem de Petrônio, Auerbach associou o delineamento desse ente fictício à compreensão que o autor possuía da hierarquia social. Os antigos romanos, segundo o crítico, careciam de percepção das forças históricas. Esta indiferença levou-os a conservar a rígida tripartição de estilos, pois a incapacidade de construir vínculos entre economia, política e a vida de um indivíduo resultava em uma compreensão estritamente moral da existência. Assim, a situação que havia levado um sujeito a tornar-se escravo ou artesão prescindia de forças sociais para ser compreendida. Esse entendimento era obtido pela conjectura de que ações reprováveis haviam vaticinado sua sorte. Consequentemente, ao ser apresentado em um texto literário latino, um servo, ou um operário, sempre estaria em situações jocosas que realçassem sua torpeza moral e justificassem sua condição. Um patrício, por seu turno, inevitavelmente seria exibido em episódios trágicos que acentuassem a gravidade de sua conduta e seu caráter altaneiro.

Do exposto, depreende-se que não há um real estanque, apenas formas instáveis de conceder significações, assim como não existe uma tipologia dos gêneros ou dos estilos literários fixa, mas, convenções textuais que, vinculadas a circunstâncias culturais e sociais, mudam, reconfigurando os liames entre forma e conteúdo e materializando ficcionalmente a suposta "realidade".

Após essas considerações, um questionamento se faz pertinente: como as totalidades elencadas no tópico anterior foram apreendidas ficcionalmente? O próprio Auerbach (2013) levou a cabo essa investigação nos textos homéricos. Segundo o autor alemão, a construção exitosa das personagens e uma hábil representação da realidade nesses poemas possuía vínculos com a percepção dos atos enquanto cerne da fortuna dos homens, o que deu origem à distensão temporal e à execução lapidar características do estilo
${ }^{6}$ Segundo Costa

Lima (2002, p. 272)

os gêneros são: “[...] quadros de referência, de existência histórica e tão-só histórica; variáveis e mutáveis, estão sintonizados com o sistema da literatura, com a conjuntura social e com os valores de uma cultura”.

${ }^{7}$ Esta classificação ortodoxa apregoava que as ações de membros das classes senhoriais deveriam ser apresentadas em molduras heroicas ou trágicas, pressupondo um acentuado pendor de estilização, enquanto a vida cotidiana de tipos modestos, necessariamente, seria exposta em caixilhos deformadores que, utilizando um estilo cômico, lhes concederia uma dimensão burlesca e caricatural. No permeio desses extremos estaria a apresentação de episódios campesinos em estilo que, se não deformava, era humilde e buscava delinear cenas leves e aprazíveis. 
homérico. Deste modo, as atitudes, nesse texto, seriam tão relevantes que o poeta grego sempre as definia com precisão, pondo-as no primeiro plano de seu relato. Se ocorresse a alusão a algum episódio passado, esse não viria a tona por meio de uma recordação que apenas listasse, de maneira breve, uma nuance remota e auxiliadora na compreensão do presente, mas através da apresentação direta do fato, ou seja, a narrativa seria dilatada a um tempo longínquo no qual determinada ocasião ou ato seriam descritos com todas as nuances possíveis. Assim, à totalidade ontológica corresponderia um acabamento estilístico que buscava apreender ficcionalmente as integrações homem/natureza e ação/destino.

Por seu turno, a adequação entre sujeito e a organização política imperial, típica do mundo romano e das monarquias dos séculos XVI e XVII, foi efetivada ficcionalmente por intermédio de uma obediência ao cânone dos estilos. Nesse contexto marcado pela rígida estratificação social, essa demarcação de classes possuía justificativas que prescindiam das forças históricas, filiando-se a uma compreensão moral e religiosa da existência. Assim, a ascensão de um homem a um posto relevante procedia de suas ações eminentes e de sua fortuna (fatum). Esse, porém, ao prosperar ocupava posição relevante no império e sua imagem sintetizava a si e esse constructo político. Assim, a apresentação de um guerreiro ou de um político romano ocorria sempre em estilo grave, por sua vez, um agricultor era exposto em um enquadramento simples, mas gracioso, e o conteúdo baixo, digno de reprovação e vergonhoso ao império, era deformado nas molduras cômicas. Desse modo, a totalidade política pressupunha formas literárias distintas para apresentar as células sociais nas quais os homens se inseriam em seu interior.

A totalidade identitária estabelecida entre um indivíduo e os demais membros de uma nação encontrou no romance a forma ideal de sua apreensão ficcional. ${ }^{8}$ Embora, no interior dessa comunidade, cada homem pudesse ocupar uma função distinta, esses encontravam, nas referências nacionais, as balizas orientadoras de sua existência e os modelos de conduta dignos de louvor ou censura. Ademais, uma pluralidade de formas que encaixilhasse cada um desses papeis sociais numa moldura distinta, como ocorria na antiguidade, seria inviável. Assim, na ascensão do romance e na sua tentativa de apreender ficcionalmente a nação, a antiga teoria dos gêneros foi abolida. Essa forma, então, apresentava, em um único estilo, homens distintos, possuidores de vidas e destinos distintos, mas partilhantes das mesmas referências, reconhecendo-se nelas, e submissos ao destino nacional. Watt (2010, p. 30), comentando a heterogeneidade dessa forma, afirma:

[...] tanto as inovações filosóficas quanto as literárias devem ser encaradas como manifestações paralelas de uma mudança mais ampla - aquela [...] que substituiu a visão unificada de mundo da Idade Média por outra muito diferente, que nos apresenta essencialmente um conjunto em evolução, mas

\footnotetext{
${ }^{7}$ As palavras de Lukács (2012, p. 55) são sugestivas: “O romance é a epopeia de uma era para a qual a totalidade extensiva da vida não é mais dada de modo evidente, para a qual a imagem do sentido à vida tornouse problemática, mas que ainda tem por intenção a totalidade."
} 
sem planejamento, de indivíduos particulares vivendo experiências particulares em épocas e lugares particulares.

E Anderson (2017, p. 54-56), associando essa heterogeneidade à nação, complementa:

A nossa concepção de simultaneidade levou muito tempo para ser preparada, e não há dúvida de que o seu surgimento está ligado, de maneiras que ainda precisam ser estudadas mais a fundo, ao desenvolvimento das ciências seculares. [...]. Entenderemos melhor por que essa transformação foi tão importante para a gênese da comunidade imaginada da nação se considerarmos a estrutura básica de duas formas de criação imaginária que floresceram pela primeira vez na Europa durante o século XVIII: o romance e o jornal. Consideremos em primeiro lugar a estrutura do romance ao velho estilo, típica não só das obras-primas de Balzac, mas também de qualquer literatura barata da época. [...]. Todas essas ações são executadas ao mesmo tempo no relógio e no calendário, mas por agentes que não precisam se conhecer, e esta é a novidade deste mundo imaginado que o autor invoca no espírito de seus leitores.

A ideia de um organismo sociológico atravessando cronologicamente um tempo vazio e homogêneo é uma analogia exata da ideia de nação, que também é concebida como uma comunidade sólida percorrendo constantemente a história [...] (Grifo nosso)

Afora esse aspecto, no interior da nação, um homem poderia modificar a sociedade em que vivia, alterar sua situação nessa comunidade, ou ser transformado pelas atitudes de outros viventes. A rígida classificação dos gêneros já não daria conta dessas alterações. Dessa forma, a totalidade identitária que não apagava as distinções entre os membros de uma nação, mas realçava sua semelhança, apresentando-os como pertencentes e submissos à estrutura nacional, encontrou na heterogeneidade do romance a forma ideal apara sua realização fictícia.

Outra forma, bem distinta do romance, mas igualmente exitosa na apreensão da totalidade nacional foi o discurso historiográfico. O romance articulava episódios heterogêneos, mas ocorridos em um arco temporal limitado, à nação. A história associava fatos ocorridos em épocas diversas, vinculando-os ao destino nacional. Esses eventos eram arrancados de uma massa amorfa de ocorrências e passavam a carregar a marca da nacionalidade. Esse processo ocorria porque a história era, e continua a ser, construída sobre o fio da memória que, por sua vez, implica a seleção subjetiva de acontecimentos da passado, tendo por base critérios e vivências do presente. Como a partir do século XVIII, a nação tornou-se o constructo que passou a mediar as relações do homem com o mundo, o sujeito passou a vislumbrar, no passado, índices da consciência e das idiossincrasias nacionais. Tinha-se, então, aquilo que Walter Benjamin intitulou de passado carregado de agora: 
A verdadeira imagem do passado passa por nós de forma fugidia. O passado só pode ser apreendido como imagem irrecuperável e subitamente iluminada no momento do seu reconhecimento. [...]. Porque é irrecuperável toda a imagem do passado que ameaça desaparecer com todo o presente que não se reconheceu como presente intencionado nela. (BENJAMIN, 2016, p. 11)

Embora Lukács não tenha estudado o discurso historiográfico, ele forneceu contribuições para sua análise. O crítico húngaro ponderava que a obra sempre articulava a vida empírica a um destino, ${ }^{9}$ retirando-a de uma arbitrariedade e lhe concedendo uma forma. Nesse processo, os inúmeros desdobramentos possíveis ao homem são limitados, organizados em um todo coerente e o ser inconstante e caótico adquire alma, ou seja, um enredo que é sua essência. Procedimento equivalente pode ser observado no discurso historiográfico visto que o historiador concede realce a alguns eventos e negligencia outros, impondo um arranjo aos fatos do passado. Esse enredo se constitui no próprio âmago da nação, ou seja, na sua história.

\section{A nação e as histórias literárias nacionais: os limites de uma perspectiva}

Antonio Candido, nas páginas iniciais de sua conhecida Formação da literatura brasileira (2013), elencou a tríade produtor - mecanismo transmissor - receptor à condição de critério decisivo para a constituição de uma literatura nacional. Segundo o crítico, somente essas estâncias viabilizariam o surgimento de uma tradição, no interior da qual, temas, mentalidades e formas poderiam ser compartilhadas ou rechaçadas, conscientemente, por gerações distintas. Bem construída e desde a segunda edição da obra apresentada pelo autor como uma possibilidade, a conhecida hipótese de Candido foi elencada por alguns de seus discípulos à condição de verdade incontestável. Essa conjectura, porém, possui limitações e, ao menos duas dessas insuficiências, podem ser facilmente percebidas. São elas: I) Cândido identifica tradição com tradição nacional; II) O crítico averigua sua tríade no interior de uma esfera pública.

A tradição, ou seja, uma genealogia de poetas e prosadores com afinidade estilística e temáticas entre si, precede a ideia de nação. Nos séculos XVI e XVII, os letrados integrantes do corpo místico ou administrativo de um estado monárquico emulavam os textos uns dos outros, ou seja, compunham variantes de um poema, buscando exceder, em engenho, o original. Essas variações não eram imitações servis, mas novas composições que, mantendo vínculos técnicos e temáticos com a primeira obra, elencavam o letrado emulado à condição de auctoritas, ou seja, um autor que, tendo composto um texto belo e engenhoso se convertia em modelo para futuras emulações. Assim, é possível afirmar que antes do século XVIII já havia o compartilhamento de técnicas e assuntos entre letrados, constituindo-se

\footnotetext{
${ }^{9}$ Toda escrita representa o mundo no símbolo de uma relação de destino; o problema do destino determina em toda parte o problema da forma. Essa unidade, essa coexistência, é tão forte que um elemento nunca vem à tona sem o outro, e uma separação, também aqui, só é possível na abstração. (LUKÁCS, 2015b, p. 39)
} 
uma traditio. Essa, porém, não era nacional e não tinha como ser, pois, a totalidade vigente não era identitária, associada a uma nação, mas política, acoplada a um estado monárquico.

Por seu turno, examinar a presença de produtores e receptores de textos e dos consequentes mecanismos de difusão dessas obras somente na esfera pública ${ }^{10}$ também é uma postura redutora. Os textos compostos antes do século XVIII eram vocalizados em recitais organizados na corte, em ambiente clericais ou em locais públicos, sendo posteriormente registrados em códices. Dessa forma, essas obras possuíam uma circulação limitada, mas não prescindiam das estâncias presentes na tríade de Cândido. Como o acesso a uma formação que desenvolvesse as habilidades necessárias à composição e compreensão de um texto era privilégio de poucas classes, a produção e recepção desses escritos era restrita, não alcançando um grande público, porém, não deixava de ocorrer.

Após essas considerações, é possível discernir que elencar a nacionalidade e a esfera pública à condição de critério e âmbito a partir do qual e no qual uma literatura se desenvolveria é problemático. O que fazer com os autores anteriores a 1750 que nos seus escritos problematizaram a realidade da colônia? Seria viável afirmar que, por não serem publicados nos tipógrafos e por não serem lidos pelo grande público, simplesmente não circulavam? Antes de apontar prováveis respostas a esses questionamentos, é necessário averiguar melhor o pensamento do crítico uspiano.

Candido (2013, p. 27), ainda nas páginas iniciais de sua obra, sugere ao leitor uma filiação de pensamento: “O leitor perceberá que me coloquei deliberadamente no ângulo dos nossos primeiros românticos e dos críticos estrangeiros que [...] localizaram na fase arcádica o início da nossa verdadeira literatura [...]”. Na primeira metade do século XIX, afluíram ao Brasil alguns estrangeiros relevantes pelo influxo que dirigirão aos moços do período. Esses cultivaram o grão que germinaria espesso entre os primeiros românticos: o assombro ante a natureza brasileira. Ferdinand Denis, morando no Brasil no segundo decênio do século XIX, momento assinalado pelas angustias emancipatórias, bosquejou uma tradição literária nacional. Denis cria que a nascente nação deveria libertar-se do jugo das imagens europeias, cultivando quadros tipicamente nacionais.

As imagens tropicais colhidas pelo olhar eurocêntrico de Denis e recolhidas em seu volumoso calhamaço e as referências a um continuum orgânico de autores nacionais foram sorvidas pelos jovens escritores do período. Estes moços, aos poucos se conscientizaram de que o país já possuía uma genealogia própria de literatos e que nas publicações destes autores havia intuições que se devidamente cultivadas poderiam originar uma literatura tão original quanto a nação recém-independente. Cabe aqui uma observação: a obra da primeira geração romântica vai obliterar certos aspectos da produção dos escritores que os precederam e apreciar outras
${ }^{10}$ Compreenda-se esfera pública na acepção endossada por Eagleton (1991, p. 3): "Situada entre o Estado e a sociedade civil, essa esfera pública burguesa [...] abrange todo um domínio de instituições sociais clubes, jornais, cafés, periódicos - nos quais os indivíduos se reúnem para o livre e equitativo intercâmbio de um discurso racional [...]”. 
nuances. Esta depreciação/valoração, entretanto, obedece a um esquema bem definido. As matizes valoradas eram intuições que na obra dos primeiros românticos já estavam bem desenvolvidas. Um exemplo: Marília de Dirceu de Tomás Antônio Gonzaga teve sua leitura alterada pelos românticos que vislumbraram nos queixumes de amor de Dirceu referências ao episódio da deportação de Gonzaga para a África, decorrente de seu envolvimento com a conjuração mineira. A obra, então, tornou-se, para esses, um manifesto das mazelas oriundas da dominação portuguesa sobre a colônia. ${ }^{11}$

Esse breve excurso mostra que para a geração coeva à independência, grupo pelo qual Cândido possui certa simpatia, o passado interessava à medida que predizia algo que entre eles já estaria sedimentado, ou seja, os autores nacionais do passado eram aqueles que haviam antecipados temas, imagens e mentalidades elencados durante a independência à condição de símbolo da nação. Cândido, embora proponha um sistema coerente e bem acabado, acaba partilhando da mesma limitação. Os autores anteriores ao século XIX que o interessam são aqueles que anteciparam a mentalidade e as referências simbólicas nacionalistas. O conceito de tradição, a tríade produtor - mecanismo transmissor - receptor e a noção de esfera pública, bases de seu sistema, servem e o interessam à medida que disseminam essas ideias. Cândido, assim, não deixa de lançar aos séculos XVI e XVII um olhar anacrônico. Como buscar nesse período mentalidades associadas a um conceito ainda inexistente? Assim como o conceito de nação não dá conta da totalidade histórica de um território, ${ }^{12}$ a noção de nacionalismo literário seria insuficiente, pois, não abarcaria autores que, anteriores ao século XIX, ficcionalizaram nos seus escritos as nuances do contexto sem necessariamente tomá-lo como nação.

A crítica mais contundente ao sistema de Antônio Cândido proveio de João Adolfo Hansen (2004). Esse, ao tratar de Gregório de Matos, mesmo sem ter a intenção, acabou desnudando as limitações de sua teorização. Hansen, ao cruzar a obra de Gregório com as artes poéticas da época, averiguou que essas, ao contrário do que ocorreria após o romantismo, priorizavam a emulação e não a originalidade. Ao comparar os mesmos escritos com os documentos eclesiásticos coevos, verificou que a sátira do autor baiano era estruturada sobre uma escala eclesiástica, ou seja, os valores tidos por padrão eram uma mistura da mesotes aristotélica com os pressupostos morais católicos. Assim, quem se afastava desse parâmetro estava apto a ser alvo de suas sátiras. Por fim, ao cotejar os versos do autor baiano com as atas da câmara de Salvador, o crítico chegou a seguinte conclusão: muitas das peripécias políticas do período eram avaliadas em seus versos segundo os critérios morais referidos.

Três pontos da tese de Hansen contrapõem as ideias de Candido: I) A constatação de que no século XVII havia, entre os letrados, um influxo de formas e temas, dado oposto ao isolamento e à inercia apontados pelo
${ }^{11}$ Segundo Kothe (2000, p. 42-44) esta perspectiva deprecia características vigentes no período em que o texto veio a lume: "O que o impulso nacionalista não pode nem quer perceber nesta “tragédia lírica” é que a idealização da figura amada faz parte de antiga tradição católica, formulada de modo lapidar na literatura italiana por Dante e por Petrarca.

[...]. A "culpa" de o amor de Marília e Dirceu ter sido impossível não é da repressão portuguesa, como o brasileiro costuma ler".

${ }^{12}$ Candido, por vezes, parece enxergar em uma nação a única ordenação política e cultural capaz de integrar os homens, desconsiderando, por exemplo, os estados absolutistas: [...] o nacionalismo artístico não pode ser condenado ou louvado em abstrato, pois é fruto de condições históricas - quase imposição nos momentos em que o Estado se forma e adquire fisionomia nos povos antes desprovidos de autonomia ou unidade. (CANDIDO, 2013, p. 29) 
autor da Formação como característicos das manifestações literárias; II) A relativização dos critérios românticos de originalidade e criatividade enquanto balizas adequadas para a avaliação de um texto seiscentista; III) A constatação de produtores, receptores e meios de transmissão no interior da estrutura monárquica.

Dessa forma, se em uma comunidade na qual os indivíduos já se concebem enquanto nação, as definições de esfera pública e originalidade ${ }^{13}$ já eram viáveis, muitos dos princípios que constituíam as linhas de força das poéticas seiscentistas estavam associados às práticas sociais da monarquia. Por exemplo, falou-se, em parágrafos anteriores, da vocalização do que se escrevia. Nessas ocasiões, alguns ouvintes, que compartilhavam uma formação semelhante a do compositor do texto, eram capazes de emulá-lo, ou seja, compreendendo o assunto, ou o predicado, do texto original e as técnicas empregues para torná-lo engenhoso, o expectador era capaz de compor uma variante desta peça, superando-a. Na Bahia seiscentista, por exemplo, essa era uma operação corriqueira:

[...] entre 1680 e 1700 , os poetas de Salvador se reuniam nas tardes de sábado na Quinta do Tanque, chácara onde os jesuítas aclimatavam plantas da Ásia e da África, entregando-se a concursos de improvisação poética [...]. As agudezas evidenciavam o engenho e a perícia técnica dos autores, sendo aplaudidas como signos de discrição. Os poemas oralizados nessa e em outras situações formais e informais de Salvador eram, muitas vezes, transcritos em folhas avulsas [...] (HANSEN, 2008, p. 186)

Uma das consequências dessa emulação era o arrefecimento do impulso criativo individual e a primazia concedida à noção de poema enquanto fruto de uma operação racionalizante. Assim, a subjetividade do indivíduo criador não era completamente apagada, mas, em parte, se deslocava da consciência que, aparentemente, confessa algo para o intelecto que seleciona a matéria a ser tratada (inventio), dispondo-a da maneira mais adequada (dispositio) e ornando-a com primor (elocutio). Hansen (2008, p. 177), comentando esse procedimento, afirma:

Como imagens retóricas, eram extraídas de repertórios ou elencos prefixados, valorizando-se a novidade de sua recombinação em usos inesperados. Hoje, podem parecer mecânicas e frias [...] uma vez que o romantismo que forma a cultura do país induz a crer que todo trabalho de desproporção e acúmulo é sintoma de alguma espécie de dilaceramento [...]

Desse modo, a apreciação adequada dessa produção pressupõe um trabalho que leve em conta as categorias estéticas e as peculiaridades políticas e sociais do período, pois, produzidos por um cortesão, por um clérigo, ou por qualquer outro membro do corpo administrativo real, os únicos viventes, nessas sociedades estratificadas, a possuírem uma formação adequada
${ }^{13}$ Uma nascente esfera pública nacional principiou em 1808 com o tênue aumento do número de leitores decorrente de alguns avanços técnicos que viabilizaram a publicação e a circulação de livros. O culto da originalidade surgiu com a queda da antiga teoria dos gêneros. 
à compreensão e produção das belas letras, esses textos eram avaliados por pessoas que, além de possuírem uma formação semelhante à de seu criador, estavam inseridas, ou nas mesmas, ou em classes sociais próximas, compartilhando os mesmos valores.

Essa breve análise dos princípios norteadores da Formação da Literatura Brasileira de Antonio Candido e a comparação desses com a abordagem levada a cabo por João Adolfo Hansen no estudo das belas letras do Brasil colônia evidencia o seguinte aspecto: o vínculo identitário estabelecido na modernidade entre o homem e a nação à medida que o submeteu ao destino nacional, criando-lhe uma perspectiva de futuro, também produziu uma visão unívoca do passado. Os fatos ocorridos, assim, em um tempo longínquo recebiam atenção se antecipassem esse organismo da modernidade: a nação. Essa, convertendo-se nas lentes a partir das quais a história passou a ser compreendida, tornou estranha ao sujeito moderno as duas outras formas de integração do indivíduo no mundo apresentadas nesse ensaio: a realidade mítica e os regimes monárquicos.

O integrante de uma nação passou a enxergar no mythos antigo um mero repositório de narrativas fantásticas sem perceber que os símbolos e as narrativas já absorvidas e continuamente reproduzidas no cotidiano cumprem uma função semelhante àqueles: orientá-lo em meio ao mundo. Esse papel configurador do real e ordenador da história exercido pela nação influenciou também a produção e a compreensão das manifestações estéticas. Dessa forma, o critério nacionalidade passou a ser o princípio estruturador dos cânones literários modernos. Essa baliza, porém, como qualquer outra, é, ao mesmo tempo, excludente e manipuladora, pois, reconfigura os textos antigos, realçando significados que no instante de sua produção não eram latentes ou, quando as formas e os conteúdos desses já lhe são estranhos, negligencia-os.

\section{Considerações finais}

No primeiro tópico desse ensaio foram apresentados diferentes modos de percepção do mundo circundante. O sujeito inserido em cada um desses sistemas culturais assimilaria uma visão de si, do real e da história. Cada um desses modos específicos de apreensão do real também pressupunha um arranjo próprio de formas através das quais seriam ficcionalizados. As produções literárias, assim, à medida que transladavam a sua estrutura uma visão historicamente orientada do universo, funcionavam como estâncias reprodutoras de práticas e referências simbólicas e, não por acaso, em contextos de totalidades ontológicas e políticas, adquiriram uma acurada função didática.

Nos tempos modernos, embora a subjetividade tenha privilegiado a diferença e o original, detratando a semelhança e a imitação, coube à nação 
enfeixar o heterogêneo, dando aos homens a sensação de pertencimento a uma estrutura pelos quais eram responsáveis e a partir da qual suas vidas estavam intimamente ligadas. O romance, forma literária por excelência desse período, não reduziu seu conteúdo ao encômio desse constructo, mas sempre que expunha os alvedrios e as inquietações do sujeito moderno, apresentava-o como pano de fundo. Dessa forma, chega-se a duas constatações: I) As várias condutas e destinos provenientes da subjetividade, ao invés de instaurar a diferença total entre os homens, originaram uma imagem capaz de apreender a complexidade do ser, permitindo uma identificação entre esses e constituindo o romance em espelho no qual o sujeito vai se mirar para se reconhecer enquanto feixe de possibilidades; II) A nação estabeleceu-se como totalidade viável nos tempos modernos justamente por não apagar os alvitres do eu, mas por associar destino individual e história nacional. Assim, os homens podiam agir como bem quisessem, mas somente no interior da nação iriam adquirir uma dimensão social e política.

As histórias literárias nacionais, por sua vez, no afã de criar uma linha genealógica para as produções estéticas são projeções viáveis, porém, falíveis, de um passado, pois, subordinam as formas de outras épocas a critérios hodiernos, condensando uma exuberância de significações em sentidos sedimentados e teleologicamente orientados.

Antonio Candido e João Adolfo Hansen, dessa forma, distinguem na sua compreensão da literatura porque, enquanto o primeiro expande às obras produzidas nos regimes monárquicos os critérios de valoração estética e classificação adotados no interior da totalidade nacional, o segundo considerou o distanciamento histórico, compreendendo que os valores presentes nas monarquias e as formas que a materializavam só podiam ser compreendidos e possuíam legitimidade no interior de uma totalidade há muito desaparecida.

\section{Referências}

ANDERSON, Benedict. Comunidades imaginadas: reflexões sobre a origem e a difusão do nacionalismo. Tradução de Denise Bottman. São Paulo: Companhia das Letras, 2011.

AUERBACH, Erich. Mimesis: a representação da realidade na literatura ocidental. 6. ed. São Paulo: Perspectiva, 2013.

BENJAMIN, Walter. O anjo da história. Tradução de João Barrento. 2. ed. Belo Horizonte: Autêntica, 2016.

CÂNDIDO, Antônio. Formação da literatura brasileira: momentos decisivos, 1750-1880. 14. ed. Rio de Janeiro: Ouro sobre Azul, 2013.

COSTA LIMA, Luiz. A questão dos gêneros. In: Teoria da

literatura em suas fontes. Rio de Janeiro: Civilização Brasileira, 2002. 
EAGLETON, Terry. A função da crítica. São Paulo: Martins Fontes, 1991.

HALL, Stuart. A identidade cultural na pós modernidade. Tradução de Tomaz Tadeu da Silva e Guacira Lopes Louro. 7. ed. Rio de Janeiro: DP\&A, 2003.

HANSEN, João Adolfo. A Sátira e o Engenho: Gregório de Matos e a Bahia no século XVII. 2. ed. São Paulo: Ateliê Editorial, 2004.

- Barroco, Neobarroco e outras ruínas. Destiempos, México, Distrito Federal, ano 3, n. 14, p. 169-215, mar. 2008a.

HOBSBAWN, Eric. Introdução: a invenção das tradições. In:

Terence Ranger (Org.). A invenção das tradições. Tradução de Celina Cardim Cavalcante. Rio de Janeiro: Paz e Terra, 1997.

KOTHE, Flávio R. O cânone imperial. Brasília: Editora universidade de Brasília, 2000.

LUKÁCS, Georg. A teoria do Romance: um ensaio histórico-filosófico sobre as

formas da grande épica. Tradução de José Marcos Mariani de Macedo 2. ed. São Paulo: Duas Cidades; Editora 34, 2009.

. Metafísica da tragédia: Paul Ernst. In: A alma e as

formas. Tradução de Rainer Patriota. Belo Horizonte: Autêntica, 2015a.

. Sobre a forma e a essência do ensaio: carta a Leo Popper. In:__ A alma e as formas. Tradução de Rainer Patriota. Belo Horizonte: Autêntica, 2015b.

QUINT, David. Repetition and ideology in the Aeneid. Materiali e discussioni per l’analisi dei testi classici. Roma, n. 23, p. 9-54, 1989.

VIRGÍlLIO. Eneida. Tradução de Carlos Alberto Nunes. São Paulo: Editora 34, 2014.

WATT, Ian. A ascensão do romance. São Paulo: Companhia das Letras, 2010.

Recebido em agosto/2018.

Aceito em dezembro/2018. 